\title{
MANAJEMEN PELAYANAN RUANG INSTALASI GIZI RUMAH SAKIT UMUM DAERAH
}

\author{
Yustina, Kaja \\ Fakultas Ilmu Sosial dan Ilmu Politik Universitas Kapuas Sintang \\ J1. JC. Oevang Oeray Sintang Kalimantan Barat \\ Email:kajaunka@gmail.com
}

\begin{abstract}
Abstrak : Manajemen pelayanan di ruang Instalasi gizi dilaksanakan sesuai standar yang telah ditentukan dan merujuk pada SOP Rumah Sakit Umum Daerah Ade Muhammad Djoen Sintang, pelayanan khususnya menu makanan dilakukan perencanaan dengan pola sistem pengorganisasian, pengarahan (pelaksanaan) sampai pada pengawasan distribusi makanan maupun bahan makanan pasien yang dapat meningkatkan gizi pasien, pengolahan makanan, proses penyajian makanan pada pasien dilakukan oleh ahli gizi, tujuannya untuk memastikan itu sehat sehingga layak di berikan pada pasien. Namun demikian letak dapur tempat pengelolaan makanan pasien belum layak karena berdekatan dengan ruang isolasi kamar jenazah dan ipal (mesin pengolah limbah). Selain itu, tenaga gizi juga masih kurang sehingga dapat mengalami keterlambatan dalam pelayanan pendistribusian makanan.
\end{abstract}

Kata Kunci : Manajemen, Pelayanan, Pendistribusian.

\section{Pendahuluan}

Pembangunan kesehatan sebagai salah satu upaya pembangunan Nasional diarahkan guna tercapainya kesadaran, kemampuan dan kemampuan untuk hidup sehat bagi setiap penduduk dalam mewujudkan derajat kesehatan yang optimal. Undang-undang Nomor 36 Tahun 2009 Tentang kesehatan menetapkan bahwa Kesehatan adalah hak fundamental setiap warganegara, karena itu setiap individu keluarga dan masyarakat memperoleh perlindungan terhadap kesehatannya, dan negara bertanggung jawab mengatur agar terpenuhi hak hidup sehat bagi penduduknya termasuk bagi masyarakat yang tidak mampu. Pembangunan kesehatan sebagai salah satu bidang terpadu dari pembangunan Nasional mempunyai peran menentukan dalam peningkatan kualitas sumberdaya manusia. Sumber daya manusia yang berkualitas serta derajat kesehatan yang tinggi dapat memperlancar tujuan pembangunan nasional sebagaimana tercantum dalam pembukaan UndangUndang Dasar 1945. Sistem Kesehatan Nasional khususnya pembangunan kesehatan bertujuan untuk mencapai hidup sehat bagi setiap penduduk agar dapat mewujudkan kesejahteraan nasional dan keutuhan masyarakat. Untuk mewujudkan tujuan tersebut, berbagai kebijakan di bidang kesehatan telah dilaksanakan sebagai cerminan dari kesungguhan dan kemauan untuk menanggulangi masalah kesehatan.

Rumah Sakit merupakan pembinaan dan pelayanan kesehatan masyarakat yang sekaligus merupakan garda terdepan dalam pembangunan kesehatan masyarakat, berbagai upaya peningkatan kualitas pelayanan menjadi tanggung jawab semua pihak yang terkait bukan hanya tanggung jawab Rumah Sakit, oleh karenaitu Rumah Sakit sebagai pelaksana terdepan dalam upaya pelayanan pengobatan kepada masyarakat perlu mengadakan kerjasama lintas sektoral agar kegiatan yang dilaksanakan dapat berjalan dengan baik. Hal ini dapat diketahui secara jelas dengan besarnya biaya yang dikeluarkan pemerintah demi kesinambungan pelayanan kesehatan di rumah sakit, baik biaya yang menyangkut fisik, alat-alat dan biaya operasional seperti obat-obatan dan biaya pelayanan kesehatan masyarakat. Kelemahan pembangunan kesehatan dilihat dari pengadaan tenaga kesehatan yang menyangkut penyebaran tenaga yang tidak merata, dapat dirasakan oleh masyarakat khususnya Rumah Sakit Umum Daerah Sintang. Penyebaran tenaga yang dimaksud seperti tenaga dokter, perawat gigi, bidan dan tenaga kesehatan lainnya termasuk bagian pelayanan tentang gizi.

Pelayanan kesehatan tidak dapat diabaikan sebab menyangkut sumber daya manusia dari generasi ke generasi, apalagi generasi muda sebagai harapan bangsa. Dengan demikian, kesehatan merupakan modal dasar dalam pelaksanaan pembangunan bangsa, tanpa kesehatan maka sulit untuk melaksanakan aktivitas dengan baik, oleh karena itu pemerintah membuat program peningkatan gizi untuk warga masyarakat sejak lahir bahkan masih dalam kandungan dianjurkan agar 
memenuhi kebutuhan gizi untuk anak-anak, selain itu program imunisasi sudah berjalan sebagaimana yang telah diharapkan.

Namun sampai saat ini masih mendapat kendala mengingat keterbatasan dana dari pemerintah, sehingga untuk melaksanakan program tersebut pemerintah menganggarkan alokasi dana lebih banyak untuk bidang kesehatan mengingat pentingnya kesehatan warga masyarakatnya. Selain rumah sakit yang melakukan program kesehatan pemerintah telah memberikan tugas pokok dan fungsi pada puskesmas di seluruh Indonesia agar memberikan pembinaan pada masyarakat diwilayahnya. Selanjutnya bahwa puskesmas merupakan unit pelaksana teknis yang merupakan pusat pengembangan kesehatan masyarakat yang juga membina peran serta masyarakat di samping disamping memberikan pelayanan secara menyeluruh dan terpadu kepada masyarakat diwilayah kerjanya dalam bentuk kegiatan pokok. Jadi dengan demikian program puskesmas sejalan dengan program rumah sakit dimana pun, diantaranya adalah perbaikan gizi usaha Perbaikan gizi dimaksudkan untuk meningkatkan status gizi masyarakat khususnya masyarakat berpenghasilan rendah. Selain itu masyarakat juga memerlukan gizi yang cukup sehingga pemerintah berupaya dalam peningkatan status gizi dan kesehatan masyarakat baik di dalam maupun di luar rumah sakit, harus lugas dan tanggung jawab tenaga kesehatan, terutama tenaga gizi.

Sejalan dengan hal tersebut di atas, maka pengelolaan anggaran khususnya anggaran yang menyangkut gizi perlu di kelola dengan sebaikbaiknya sesuai harapan publik agar sasaran yang diinginkan dapat tercapai, oleh karena itu, perlu

Menurut Terry (dalam Manullang, 2009 : 3) bahwa bila kita mempelajari literatur manajemen, maka akan ditemukan bahwa istilah manajemen mengandung tiga pengertian yaitu:"(1). Manajemen sebagai suatu proses, (2). Manajemen sebagai kolektivitas orang-orang yang melakukan aktivitas manajemen, (3) Manajemen sebagai suatu seni (Art) dan sebagai suatu ilmu pengetahuan (Science)." Sesuai pengertian yang pertama, yakni manajemen sebagai suatu proses, berbeda-beda definisi yang diberikan oleh para ahli, menurut pengertian yang pertama itu, dikemukakan tiga buah definisi dalam Encylopedia of the Social Sience dikatakan bahwa manajemen adalah suatu proses dengan mana pelaksanaan suatu tujuan tertentu diselenggarakan dan diawasi.
Menurut Sinambela dkk (2008: 5) mendefinisikan "pelayanan publik di artikan sebagai setiap kegiatan yang dilakukan oleh pemerintah terhadap sejumlah manusia yang memiliki setiap kegiatan yang menguntungkan dalam suatu kumpulan atau kesatuan, dan menawarkan kepuasan meskipun hasilnya tidak terikat pada suatu produk secara fisik." Sejalan dengan pemikiran tersebut, bahwa dalam rangka mencapai tujuan dan ide tersebut, termasuk program pembangunan dibidang kesehatan diselenggarakan pembangunan nasional yang berkesinambungan, menyeluruh, terpadu dan terarah dalam kerangka Negara Kesatuan Repubblik Indonesia serta meningkatkan harkat dan martabat serta derajat kesehatan masyarakat menjadi tujuan utama bagi segenap bangsa Indonesia. Program pemerintah merupakan suatu rangkaian kerja sebuah organisasi tujuannya adalah untuk kepentingan organisasi yang bersangkutan, demikian juga tujuan Negara adalah untuk kepentingan seluruh warga masyarakat bangsa dan Negara, dengan tercapainya tujuan Negara harapannya tercapai juga tujuan masyarakat. Dengan demikian pelayanan pemerintah pada masyarakat semata - mata untuk kepentingan masyarakat sebagai pemberi pelayanan, oleh sebab itu pelayanan memerlukan perencanaan yang sebaik-baiknya.

Pelaksanaan pekerjaan tidak ada artinya tanpa perencanaan, sebab pekerjaan tanpa perencanaan kecendrungan mengalami kegagalan sebab sulit untuk memperkirakan apa yang terjadi baik karena pengaruh internal maupun eksternal, oleh karena itu perencanaan dalam sebuah organisasi sangat penting artinya bagi kemajuan organisasi, demikian juga manajemen pelayanan gizi di rumah sakit khususnya di ruang instalasi gizi, sebab perancanaan dapat memperhitungkan pembagian ataupun distribusi makanan yang memiliki nilai gizi bagi pasien di rumah sakit, selain mencakup distribusi juga dapat memperhitungkan menu yang cocok untuk pasien karena sudah ada ketentuannya di dasarkan pada jenis penyakit serta makanan yang cocok bagi pasien.

Berdasarkan Keputusan MENPAN Nomor 63 Tahun 2004 menyatakan bahwa, "Hakikat pelayanan publik adalah pemberian pelayanan prima kepada masyarakat yang merupakan perwujudan kewajiban aparatur pemerintah sebagai abdi masyarakat. Menurut Ratminto dan Atik Septi Winarsih (2015:6) mengatakan bahwa, "Perencanaan tidak lain merupakan kegiatan untuk menetapkan tujuan yang akan dicapai beserta caracara untuk mencapai tujuan tersebut. Selanjutnya 
menurut Gronroos sebagaimana dikutif oleh Ratminto dan Atik S.W. (2015 : 2) "Pelayanan adalah suatu aktivitas atau serangkaian kegiatan aktivitas yang bersifat tidak kasat mata (tidak dapat diraba) yang terjadi sebagai akibat adanya interaksi antara konsumen dengan karyawan atau hal-hal lain yang di sediakan oleh perusahaan pemberi pelayanan yang dimaksudkan untuk memecahkan permasalahan konsumen/pelanggan."

Pemerintah wajib memberikan pelayanan pada masyarakat sesuai dengan Undang-Undang Nomor 23 Tahun 2014 Tentang Pemerintah Daerah, pasal 11 ayat (2) mengenai urusan pemerintah wajib yang berkaitan dengan pelayanan dasar salah satunya adalah tentang kesehatan. Dengan demikian bahwa kesehatan sangat penting sehingga hal tersebut menjadi pelayanan yang mendasar bagi warga masyarakat dan menjadi tanggungjawab pemerintah, oleh karena itu, masyarakat memiliki hak untuk menuntut pelayanan yang sebaik-baiknya pada pemerintah. Pelayanan yang baik hanya akan terwujud jika dilakukan dengan manajemen yang benar serta di kelola dengan baik yang mencakup seluruh bidang pekerjaan baik bidang ekonomi, politik, budaya, maupun bidang kesehatan. Bidang kesehatan mencakup pemenuhan gizi masyarakat sejak dalam kandungan sampai dewasa sehingga masyarakat Indonesia tidak ada lagi yang menderita kekurangan gizi buruk. Dengan demikian, pelayanan pemerintah menjadi sangat penting bagi masyarakat, demikian juga perencanaan yang baik diharapkan memiliki dampak positif bagi masyarakat dengan berbagai penentuan strategi, kebijaksanaan, proyek, program, prosedur, metode, sistem, anggaran dan standar yang dibutuhkan untuk mencapai tujuan.

Menurut Robbins dan Mary Coulter dalam (Rusdiana, 2014 : 112) bahwa, "Manajemen adalah proses pengorganisasian kegiatan-kegiatan pekerjaan sehingga pekerjaan tersebut terselesaikan secara efektif, efisien, dan melalui orang lain. "Dengan demikian bahwa manajemen merupakan sebuah proses yang dijabarkan dalam empat fungsi secara keseluruhan mencakup perencanaan, pengorganisasian, pelaksanaan, dan pengawasan. Rusdiana dkk (2014 : 143) mengatakan alasan pentingnya perencanaan dalam manajemen adalah sebagai berikut: "Tujuan menjadi jelas dan terarah, perencanaan sebagai langkah awal dari pencapaian tujuan akan memberikan arah dan kejelasan tujuan tersebut sehingga semua komponen ataupun elemen-elemen dalam organisasi mengetahui dengan baik tujuan yang hendak dicapai, Semua bagian yang ada dalam organisasi akan bekerja kearah satu tujuan yang sama.

Menurut Hasibuan (2014 : 21) bahwa,"Pengarahan adalah mengarahkan semua bawahan, agar mau bekerja sama dan bekerja efektif untuk mencapai tujuan." Dalam arti pengarahan memberikan masukan serta memberikan arah pada bawahan untuk dapat melaksanakan tugasnya dengan baik, serta memahami bidang tugas yang diberikan kepadanya. Dengan demikian pengarahan bertujuan membentuk hubungan yang menghubungkan tindakan dengan tujuan. Pendapat di atas menunjukkan bahwa pengarahan bagian dari pelaksanaan suatu kebijakan atau program dimana akibat tersebut itu akan memiliki dampak, sehingga akan membawa suatu perubahan terhadap tatanan kehidupan dalam suatu masyarakat. Menurut Terry (1986:57) mengemukakan bahwa "actuating" merupakan usaha menggerakkan anggota-anggota kelompok sedemikian rupa hingga mereka berkeinginan dan berusaha untuk mencapai sasaran perusahaan dan sasaran anggota-anggota perusahaan tersebut oleh karena para anggota itu juga ingin mencapai sasaran-sasaran tersebut".

GR.Terry (dalam Hasibuan, 2014 : 21) mengatakan bahwa," Actuating is setting all members of the group to want to achieve and to strike to achieve the objective willingly and keeping with the managerial planning and organizing efforts."(Pengarahan adalah membuat semua anggota kelompok agar mau bekerja sama dan bekerja secara ikhlas serta bergairah untuk mencapai tujuan sesuai dengan perencanaan dan usaha-usaha pengorgainsasian). Sejalan dengan pendapat ahli tersebut di atas, bahwa pengarahan merupakan bentuk dengan demikian, pengarahan atau penggerakan merupakan unsur penting dalam manajemen sehingga merupakan fungsi ketiga dari manajemen, oleh karena itu, pengarahan diberikan oleh pimpinan dalam rangka peningkatan mutu pelayanan pada masyarakat dalam hal ini pasien di rumah sakit. Pelayanan terhadap pasien terutama bagian gizi di rumah sakit tidak hanya berfungsi meningkatkan atau memberikan gizi pada pasien tetapi yang dilakukan menyiapkan makanan, sejak perencanaan belanja barang makanan untuk pasien sampai pada proses pendistribusian makanan.

Keban (2014 : 107) mengatakan bahwa, "Controling yaitu menetapkan standar, menciptakan perubahan dalam mencapai tujuan, mengembangkan struktur dan proses akuntabilitas, dan mengevaluasi kinerja." Dengan demikian, pengawasan bukan berarti mencari kesalahan tetapi justru ingin memperbaiki kelemahan, 
mengembangkan serta menciptakan organisasi dalam mencapai tujuan yang telah di tentukan sebelumnya, oleh karena itu, pengawasan bertujuan agar kegiatan organisasi dapat berjalan sebagaimana yang diharapan yaitu secara efektif dan efisien sehingga, kegiatan organisasi berjalan lancar dan dapat dipertanggungjawabkan."

Berdasarkan pendapat ahli di atas, maka pengawasan membandingkan antara pelaksanaan dengan rencana, serta untuk memastikan apakah ada kendala dalam pelaksanaan pekerjaan, kemudian melaksanakan perbaikan - perbaikan secara dini dan apabila ditemukan penyimpangan dan memperolah bahan yang baru dapat digunakan untuk penyusunan program selanjutnya. Proses pengawasan merupakan hal yang sangat penting dalam melakukan pelayanan pada masyarakat, sebab wujud pengawasan menurut Mukarom (2015 : 161) adalah,"pelaksanaan fungsi administrasi dari pemerintah terhadap masyarakat, serta mewujudkan peningkatan efektivitas, efisiensi, rasionalitas, dan ketertiban dalam pencapaian tujuan dan pelaksanaan tugas pelayanan publik." Sejalan dengan hal tersebut di atas, pelayanan gizi diharapkan sesuai dengan yang direncanakan dan minimnya kesalahan atau penyimpangan yang terjadi, sehingga pentingnya pengawasan dalam pelaksanaan tugas dan pekerjaan.

\section{METODE PENELITIAN}

Penelitian ini menggunakan jenis penelitian deskriptif dengan pendekatan kualitatif, tujuan untuk memecahkan masalah yang diteliti, penelitian juga sebagai jawaban dan sekaligus memberikan solusi atas persoalan yang dihadapi. Sejalan dengan hal tersebut di atas, maka penelitian ini berkaitan dengan manajemen pelayanan.

Subjek Penelitian ini adalah Kepala Instalasi Gizi Rumah Sakit Umum Daerah Ade Mohammad Djoen Sintang, Sub. Unit Penerimaan Pengolahan, Pendistribusian dan Perbekalan Rumah Sakit Umum Daerah Ade Mohammad Djoen Sintang, Pegawai di Ruang Instalasi Gizi Rumah Sakit Umum Daerah Ade Mohammad Djoen Sintang.

Teknik pengumpulan data yang digunakan adalah wawancara, observasi, dokumentasi. Teknik analisis data dalam penelitian ini menggunakan deskriptif data, yaitu data mentah yang telah terkumpul kemudian dideskriptifkan dan digeneralisasikan serta ditarik kesimpulan secara kualitatif. Fungsi dari analisis data adalah memperlakukan data empiris ke dalam suatu bentuk yang dapat diinterpretasikan dan dapat pula memberikan kejelasan sebagai jawaban atas pengujian dan pemecahan masalah. Dalam penelitian ini digunakan analisis kualitatif seseuai dengan tujuannya untuk membuat deskriptif secara sistematis, faktual dan akurat mengenai fakta-fakta, sifat serta hubungan antara fenomena sosial yang diselidiki.

\section{HASIL PENELITIAN}

Rumah Sakit Umum Daerah Ade Muhammad Djoen Sintang adalah Rumah Sakit milik Pemerintah Kabupaten Sintang yang merupakan Rumah Sakit Rujukan Regional Keputusan Bupati Sintang Nomor 1254 Tahun 2010 tanggal 30 juli 2010 tentang izin penyelenggaraan Rumah Sakit dengan nama Rumah Sakit Umum Daerah Ade Muhammad Djoen Kabupaten Sintang Provinsi Kalimantan Barat yang diperpanjang dengan Keputusan Bupati Sintang Nomor : 445/ 1330/ KEP-RSUD/Tahun 2015 tanggal 25 Mei 2015 tentang Izin Perpanjangan Izin Operasional Rumah Sakit Umum Daerah Ade Muhammad Djoen Sintang dan Peraturan Daerah Kabupaten Sintang Nomor 2 Tahun 2008 tentang Organisasi Perangkat Daerah Pemerintah Kabupaten Sintang yang dijabarkan dalam Peraturan Bupati Sintang Nomor 53 Tahun 2008 tentang Struktur Organisasi dan Tata Kerja Rumah Sakit Umum Daerah Ade Muhammad Djoen Sintang adalah Rumah Sakit Type C non Pendidikan.

Visi : Menjadi Rumah Sakit yang profesional dan menghasilkan pelayanan kesehatan yang berkualitas untuk masyarakat kabupaten Sintang dan Kalimantan Barat."Untuk meyakinkan bahwa visi tersebut bersifat logis dan achievable (dapat dicapai), maka ada indikator yang akan menunjukkan di masa depan apakah visi tersebut sudah tercapai atau belum. vIndikator untuk "Profesional" adalah SDM di RSUD Ade Muhammad Djoen Sintang bekerja pada posisi yang sesuai dengan kompetensinya. vIndikator untuk "Berkualitas" adalah RSUD Ade Muhammad Djoen Sintang diakui secara nasional melalui pencapaian akreditasi oleh KARS. vIndikator untuk pencapaian cakupan geografis pelayanan adalah RSUD Ade Muhammad Djoen Sintang menjadi rujukan bagi masyarakat Kabupaten Sekadau, Kabupaten KapuasHulu, Kabupaten Melawi dan Kabupaten Sintang dengan jumlah pasien rujukan proporsional.

Misi : Menyelenggarakan Pelayanan Kesehatan yang Komprehensif, Adil dan terjangkau 
dengan mengacu pada Standar Pelayanan Minimal dan Pelayanan Publik yang Berorientasi kepada Kepuasan Pelanggan dan Keselamatan Pasien. Menyelenggarakan pelayanan kesehatan rujukan bagi Rumah Sakit lain di kabupaten sekitarnya. Mewujudkan Sumber Daya manusia yang Profesional. Meningkatkan Sarana dan Prasarana Pelayanan Sesuai Standarisasi Akreditasi Rumah Sakit. Meningkatkan Manajemen Pelayanan Rumah Sakit yang Akuntabel Transparan, Berdaya Guna dan Berhasil Guna untuk masyarakat kabupaten Sintang dan Kalimantan Barat.”Perencanaan dalam mempersiapkan makanan bagi pasien sangat diperlukan karena harus menyesuaikan pola makanan dengan penyakit yang dihadapi, maksudnya adalah makanan tertentu boleh di sajikan pada pasien yang menderita penyakit tertentu artinya bahwa makanan yang di sajikan bagian gizi di Rumah Sakit tidak sama tetapi di sesuaikan dengan kondisi penyakit pasien, ada pasien misalnya pasien yang menderita penyakit dalam di sajikan makanan seperti bubur atau hanya makanan ringan yang di berikan, demikian juga sebaliknya. Sejalan dengan hal tersebut di atas, maka perencanaan yang dilakukan oleh Kepala Instalasi gizi adalah menyelenggarakan Asuhan Gizi terstandar pada pelayanan gizi rawat jalan dan rawat inap, menyelenggarakan Makanan sesuai standar kebutuhan gizi dan aman dikonsumsi pasien, menyelenggarakan penyuluhan dan konseling gizi pada klien / pasien dan keluarganya. Perencanaan tersebut sangat dibutuhkan karena selalu ada ke hati-hatian dalam pemberian makanan dan sesuai standar kebutuhan gizi makanan pasien sedangkan proses perencanaan terutama dalam memberikan bimbingan penyuluhan atau konseling gizi tentu Kepala Instalasi gizi memberikan instruksi atau pengarahan pada pada staf agar menjalankan tugas dengan sebaik-baiknya agar tidak keliru mengatur menu makanan pasien.

Makanan yang di sajikan melalui perencanaan mulai dari merencanakan belanja sampai pada proses memasak sudah ada ketentuan, sehingga dengan demikian, menu makanan yang di sajikan juga sesuai standar yang telah di tentukan. Di samping itu juga bahwa bagian dapur selalu menerima arahan dan petunjuk dari pimpinan kepada seluruh jajaranya. Berdasarkan hasil wawancara dengan Sub Unit Penerimaan, pengolahan pendistribusian dan perbekalan bahwa tenaga pelayanan gizi yang mempunyai kompetensi dan kemampuan melakukan pengkajian gizi, faktor yang berpengaruh terhadap gangguan gizi dan status gizi dengan cara anamnesis diet. Selain itu menegakkan diagnosis gizi berdasarkan hasil pemeriksaan yang dilakukan serta menentukan tujuan dan merencanakan intervensi gizi dengan menghitung kebutuhan zat gizi, bentuk makanan, jumlah serta pemberian makanan yang sesuai dengan keadaan pasien. Sejalan dengan hal tersebut bahwa Unit instalasi gizi memang harus memiliki ahli gizi sehingga dalam memberikan makanan pada pasien tidak mengalami kendala, serta dapat merencanakan kebutuhan khususnya yang berkaitan dengan standar gizi pasien di Rumah Sakit Umum Daerah Ade Muhammad Djoen Sintang.

Selanjutnya dalam mendistribusi makanan tidak mengalami kendala karena bagian instalasi gizi sudah melakukan pembagian tugas dan menjalankannya dengan baik. Selain hal tersebut instalasi gizi juga menyelenggarakan administrasi pelayanan gizi, oleh karena itu perencanaan kegiatan program biasanya dilakukan melalui kebutuhan di ruang gizi sesuai dengan jumlah pasien yang ada di rumah sakit khususnya pasien rawat inap melibatkan seluruh pegawai yang ada di ruangan tersebut. Sistem perencanaan dalam peningkatan gizi khususnya pasien di Rumah Sakit diberikan sesuai kebutuhan gizi dan memberikan edukasi kepada pasien dan keluarga pasien sedangkan system perencanaan belanja barang khususnya makanan dalam rangka memenuhi gizi pasien dilakukan perencanaan belanja sesuai dengan jumlah pasien, belanja tersebut dilakukan melalui pihak ketiga yang menyuplai belanja barang makanan kering dilakukan sebulan sekali sementara untuk barang makanan basah belanja setiap hari. Perencanaan distribusi makanan pada pasien adalah sesuai dengan kelas perawatan dan sesuai dietnya, makanan yang diberikan pada pasien menunya berbeda-beda kelas perawatannya.

Dengan demikian dapat menghemat dan mempercepat waktu pelayanan dan lebih mudah dipahami serta meminimumkan pekerjaan yang tidak pasti, dan menghemat waktu, serta dana dalam meningkatkan kebutuhan gizi pasien. Selanjutnya menurut para pegawai di instalasi gizi bahwa selama ini tidak ada kendala dalam memberikan makanan pada pasien karena sebelum melakukan tugas tersebut di berikan pengarahan dari Kepala instalasi gizi, namun demikian kadang-kadang ada kritikan dari pasien dan keluarga mengenai menu makanan yang di berikan alasannya, bahwa makanan tersebut tidak memilki daya tarik yang dapat menimbulkan nafsu makan, sehingga seringkali makanan yang di sajikan tidak di makan oleh pasien. Dalam arti bahwa makanan yang di sajikan tersebut dirasakan kurang cocok dengan pola makanan sehari-hari seperti biasanya. Namun 
demikian petugas memberikan penjelasan pada pasien dan keluarganya bahwa menu makanan tersebut di sesuaikan dengan kelas perawatannya dan penyakit yang di derita pasien karena tidak semua pasien cocok diberikan makanan berat (nasi putih biasa) sehingga terpaksa harus di berikan makanan ringan (bubur).

Selanjutnya makanan yang di sajikan pada pasien tentunya sudah sesuai dengan standar kesehatan dan gizi pasien sehingga tidak ada keraguan bagi pasien untuk mengkonsumsi makanan yang di berikan tersebut, perencanaan belanja barang khususnya makanan pasien adalah ahli gizi bagian unit perencanaan, mekanisme perencanaan belanja adalah membuat pesanan sehari sebelumnya untuk makanan basah, sementara menu telah dibuat untuk sepuluh hari, perputaran menu akan di ganti setiap sekali setahun, namun demikian dalam pengolah makanan harus sesuai dengan menu Cuma kadang-kadang ada kendala dalam penyediaan bahan makanan, biasanya ada bahan makanan tidak sesuai dengan pesanan sehingga harus diganti, sebab makanan yang diberikan tentu untuk meningkatkan gizi pasien, sistem pemberian makanan sesuai dengan kelas perawatan pasien oleh karena itu tentu tidak di dasarkan kelas dan jenis diagnose.

Pelaksanaan tugas yang dijalankan dalam menyiapkan makanan pasien didasarkan atas petunjuk dan arahan pimpinan, hal ini bukan tanpa alasan karena semua makanan yang diberikan harus berdasarkan standar gizi yang dapat meningkatkan derajat kesehatan pasien, oleh karena itu pimpinan sangat hati-hati dalam menyiapkan menu makanan bagi pasien agar tidak terjadi kekeliruan yang dapat menyebabkan tindakan yang fatal bagi pasien. Pimpinan memiliki kewenangan dan tanggungjawab atas makanan pasien, sesuai dengan standar operasional prosedur (SOP) yang telah di tetapkan. Pelayanan di ruangan instalasi gizi melayani semua pasien dengan penyakitnya, sistem pembagian kerja dilakukan berdasarkan uraian kerja, sementara pelayanan tidak ada perbedaan yang berbeda hanya menu makanan karena sesuai dengan kelas perawatan pasien. Pembagian pekerjaan bertujuan untuk memudahkan pekerjaan, selain hal tersebut bahwa dalam memberikan pelayanan diperlukan keterampilan dan kecakapan agar pasien dan keluarga merasa puas atas tindakan pemberi pelayanan. Sesuai dengan hasil wawancara tersebut di atas, bahwa pembagian tugas diharapkan memiliki spesifik sehingga pelayanan semakin hari semakin baik, karena semua pegawai sudah memahami kewajiban dan hak masing-masing.
Dengan memahami tugas dan kewenangan maka sistem pelayanan yang diinginkan dapat tercapai dan menjadi acuan dalam memberikan pelayanan. Pelayanan sudah dilakukan hanya letak dapur untuk menyiapkan makanan bagi pasien belum sesuai standar karena letak bangunan instalasi gizi belum memenuhi standar alasannya adalah karena masih berdekatan dengan ruangan isolasi kamar jenazah dan ipal (mesin pengolah limbah). Selanjutnya tata ruang juga masih menjadi masalah belum memenuhi standar karena tidak sesuai standar pedoman gizi Rumah Sakit, seharusnya ada letak ruangan masingmasing sub unit tetapi di ruangan instalasi gizi Rumah Sakit Umum Daerah Ade Muhammad Djoen Sintang tidak ada.

Pemerintah daerah harus memperhatikan standar-standar tersebut sehingga bukan hanya peningkatan pelayanan tetapi lebih meningkatkan tipe rumah sakit dari tipe $\mathrm{C}$ berubah menjadi tipe $\mathrm{B}$ bahkan $\mathrm{A}$. Walaupun standar tersebut bukan satusatunya metode peningkatan tipe Rumah Sakit tetapi memberikan dampak baik atau buruknya pelayanan dan penilaian masyarakat atas kondisi tersebut. Dengan demikian, sarana dan prasarana Rumah Sakit menjadi indikator pelayanan, oleh karena itu letak bangunan dan letak ruangan itu turut mempengaruhi kenyamanan dalam bekerja sehingga pemberi pelayanan tidak dapat bekerja secara maksimal, namun demikian kekurangan sarana dan prasarana tidak dapat di jadikan alasan untuk tidak melayani masyarakat apa lagi pasien di Rumah Sakit.

Berdasarkah hal tersebut di atas maka tempat pengolahan makanan atau dapur harus memenuhi persyaratan teknis higienis sanitasi untuk mencegah risiko pencemaran terhadap makanan dan dapat mencegah masuknya kotoran. Pemilihan bahan makanan untuk menjaga mutu dan keawetan makanan serta mengurangi risiko pencemaran makanan, bahan makanan, persiapan bumbu, persiapan pengolahan dan prioritas dalam memasak harus dilakukan sesuai tahapan. Distribusi makanan yang telah dimasak merupakan kegiatan terakhir dalam proses penyelenggaraan makanan sampai pada penyajian makanan kepada pasien. Distribusi makanan sudah ada ketentuan di setiap Rumah Sakit. Persyaratan distribusi makanan paling tidak tersedianya peraturan pemberian makanan rumah sakit, adanya standar porsi yang ditetapkan rumah sakit, adanya peraturan pengambilan makanan, adanya daftar permintaan makanan konsumen/ pasien, tersedianya peralatan untuk distribusi makanan dan peralatan makan, serta jadwal pendistribusian makanan yang ditetapkan. 
Berdasarkan penjelasan tersebut di atas maka semua Rumah Sakit memiliki SOP dalam pemberian makanan, sehingga menjadi acuan atau standar yang di jadikan pokok pelaksanaan tugas atau aktivitas.

Berdasarkan hasil penelitian di atas menunjukan bahwa pelaksanaan merupakan fungsi manajemen yang paling utama. Selain fungsi manajemen di atas, perencanaan merupakan aspek yang lebih menekankan pada kegiatan yang berhubungan langsung dengan orang-orang khususnya pasien di Rumah Sakit sehingga Kepala Instalasi merupakan penggerak yang berkeinginan untuk mencapai sasaran memberikan pelayanan yang terbaik bagi pasien sesuai standar gizi, memberikan bimbingan dan penyuluhan kepada pasien dan keluarga pasien, namun masih terbatas ahli gizi di Rumah Sakit, walaupun demikian Kepala Instalasi mengatakan bahwa bertekad melakukan yang terbaik bagi pasien sesuai kemampuannya. Dengan demikian ahli gizi masih belum sesuai harapan secara kuantitas sehingga pemerintah perlu memperhatikan hal tersebut supaya program peningkatan gizi Rumah Sakit dapat terlaksana dengan baik. Selanjutnya sistem pengarahan dengan lisan dan tulisan serta tata cara berkomunikasi dengan pasien sedangkan standar makanan diatur dalam pedoman gizi Rumah Sakit yang di atur oleh ahli gizi, pemberian makanan dilakukan tiga kali sehari di distribusikan jam 06.00 kemudian jam 11.00 dan jam 17.00 wib.

Pelayanan gizi rawat inap prosedur adalah pasien masuk diperawatan, kemudian dilakukan skrining gizi awal oleh ahli gizi dan perawat. Apabila pada skrining gizi awal oleh perawat skornya tidak berisiko maka tidak dilakukan skrining gizi lanjut, tetapi bila hasilnya berisiko, maka dilakukan skrining gizi lanjut. Setelah dilakukan skrining gizi lanjut dengan nilai skor berisiko maka selanjutnya dilakukan asessment gizi untuk menentukan diagnosa gizinya. Pasien yang telah ditentukan diagnosa gizinya, kemudian diintervensi gizi untuk dilakukan permintaan, pembatalan dan perubahan diet. Setelah intervensi gizi maka dilakukan perencanaan menu (dalam merencanakan menu dilakukan persiapan dan pengolahan), kemudian dilakukan penyajian makanan. Setelah makanan disajikan maka dilakukan pelayanan makanan dengan cara mendistribusikan makanan ke tiap-tiap ruang perawatan. Setelah itu pasien diintervensi gizi lagi kemudian dilakukan monitoring, evaluasi dan edukasi. Dengan demikian instalasi gizi merupakan tempat penyelenggaraan konseling dan memberikan saran serta masukan pada pasien agar memperhatikan makanan yang memiliki asupan gizi yang baik, sehingga gizi sangat penting bagi tubuh manusia, kekurangan gizi menyebabkan daya tahan tubuh sangat lemah, oleh karena itu nutrisi yang diperlukan adalah yang memiliki nilai gizi tinggi yang berdampak positif bagi kesehatan tubuh. Pemberian makanan maupun bahan makanan diperlukan pengawasan. Pengawasan dilakukan

Pengawasan yang dilakukan berdampak positif pada pelayanan gizi yaitu tercapainya tujuan yang telah ditentukan, pelaksanaan pelayanan gizi sesuai dengan yang direncanakan dan minimnya kesalahan atau penyimpangangan. Sistem pengawasan makanan yang disajikan pada pasien sesuai SOP sedangkan standar makanan yang diberikan pada pasien adalah sesuai standar aman dan sesuai standar gizi selanjutnya tindakan yang dilakukan jika makanan yang di sajikan tidak sesuai dengan standar yang telah ditetapkan. Berdasarkan hal tersebut di atas, ini menuntut adanya komitmen pemerintah dan semua pihak yang terkait untuk berusaha dan bekerja untuk mencapai standar yang telah di tetapkan terutama ahli gizi yang dirasakan belum mencukupi ketentuan sebuah Rumah Sakit yang memiliki tipe C. Sesuai dengan persoalan di atas, pemerintah harus mengganggarkan sesuai dengan kebutuhan Rumah Sakit terutama diinstalasi gizi karena ini sangat vital sekali dalam menunjang kesehatan pasien dan peningkatan gizi pasien di Rumah Sakit. Tenaga ahli gizi yang belum mencukupi kebutuhan sebuah Rumah Sakit juga harus menjadi perhatian pemerintah sehingga harus di upayakan untuk mencukupi standar yang telah di tentukan. dengan demikian kebutuhan kesehatan sangat penting dalam pelaksanaan pembangunan dibidang kesehatan dengan tujuan untuk dapat meningkatkan derajat kesehatan masyarakat. Tujuan umum pemberian makanan pada pasien adalah mempertahankan dan meningkatkan status gizi pasien dengan harapan memberikan pemulihan kepada pasien. Pelayanan yang diberikan di instalasi gizi bukan hanya pemberian makanan semata-mata tetapi juga memberikan penyuluhan pada pasien untuk mempertahankan dan meningkatkan status gizi. Kegiatan ini merupakan upaya pemerintah dalam meningkatkan derajat kesehatan masyarakat dan status gizi ayi secara berkelanjutan.

\section{KESIMPULAN DAN SARAN}

Perencanaan menu makanan sesuai dengan menu makanan pasien hanya kadang-kadang ada kendala dalam penyediaan bahan makanan, 
biasanya ada bahan makanan tidak sesuai dengan pesanan sebelum diolah. Pembagian tugas yang jelas, berdasarkan struktur organisasi bahwa Kepala Instalasi gizi sudah menjalankan tugas dengan baik sesuai dengan ketentuan yang ditetapkan, memberikan arahan dan petunjuk mengenai petunjuk pelaksanaan pekerjaan pada pegawainya dalam memberikan bimbingan sampai penditribusian makanan pada pasien, sejak perencanaan menu makanan sampai pada pendistribusian makanan oleh ahli gizi sudah sesuai dengan rencana yang telah ditetapkan untuk mencegah sedini mungkin terjadi penyimpanganpenyimpangan menu makanan dari standar yang telah di tetapkan oleh Rumah Sakit maupun standar operasional prosedur yang menjadi pedoman dan acuan Rumah Sakit. Berdasarkan pada hasil dan pembahasan serta kesimpulan di atas maka penulis mengajukan beberapa saran sebagai berikut : Makanan yang diberikan untuk meningkatkan gizi pasien, oleh karena itu sebaiknya di pertahankan dan di tingkatkan, bahan makanan yang tidak sesuai perencanaan perlu di ganti sesuai standar. Pendistribusian makanan pada pasien, sebaiknya dipertahankan dan ditingkatkan sehingga pasien merasa puas atas pelayanan yang diberikan. Pengarahan, dan petunjuk pelaksanaan tata kerja dalam meningkatkan mutu pelayanan pemberian makanan pada pasien, perlu di tingkatkan secara maksimal. Demikian juga pengawasan, khususnya ahli gizi masih belum memenuhi standar Rumah Sakit tipe C yang sebaiknya mengajukan penerimaan tenaga ahli gizi untuk mencukupi

\section{DAFTAR PUSTAKA}

Anggara, Sahaya. 2015. Metode Penelitian Administrasi. Bandung: CV. Pustaka Setia

Anshari. 2009. Aplikasi Manajemen Pengelolaan Obat Dan Makanan, Edisi Pertama. Yogyakarta : Nuha Medika

Fahmi, Irham. 2016. Perilaku Organisasi Teori, Aplikasi, dan Kasus. Bandung : Alfabeta.
Gulo,W. 2010. Metode Penelitian. Jakarta : PT.Gramedia

Hasibuan, Malayu,SP. 2014. Organisasi dan Motivasi Dasar Peningkatan Produktivitas. Jakarta : PT.Bumi Aksara.

Keban, Yeremias T. 2014. Enam Dimensi Strategis Administrasi Publik, Konsef, Teori dan isu. edisi cetak ketiga. Yogyakarta : Penerbit Gava Media.

Manullang, M. 2009. Dasar-Dasar Manajemen. Yogyakarta: Gajah Mada University Press.

Mahsun, Mohamad. 2016. Pengukuran Kinerja Sektor Publik. Yogyakarta : BPFE

Mukarom, Zaenal dkk. 2015. Manajemen Pelayanan Publik. Bandung: Pustaka Setia.

Moleong, L.J. 2002. Metodologi Penelitian Kuantitatif. Bandung: PT. Remaja Rosdakarya.

Rusdiana dkk. 2014. Sistem Informasi Manajemen. Bandung : Pustaka Setia

Siswandi dan Indra Iman. 2009. Aplikasi Manajemen Perusahaan Analisis Kasus dan pemecahannya. Jakarta : Mitra Wacana Media.

Syafiie, Inu Kencana. 2011. Manajemen Pemerintahan. Bandung : Pustaka Reka Cipta.

Taufiq, Rohmat. 2013. Sistem Informasi Manajemen..Konsep Dasar, Analisis dan Metode Pengembangan. Yogyakarta : Graha Ilmu.

Peraturan Perundangan:

Keputusan MENPAN Nomor 63 Tahun 2004 Tentang Prinsip Pelayanan Publik

Peraturan Menteri Kesehatan Republik Indonesia Nomor 26 Tahun 2013 Tentang Penyelenggaraan Pekerjaan dan Praktik Tenaga Gizi.

Undang-undang Nomor 36 Tahun 2009 Tentang kesehatan.

Undang-Undang Nomor 23 Tahun 2014 Tentang Pemerintah Daerah 